\title{
Testy S.I.F.T.E.R. oraz L.I.F.E.-R. i ich zastosowanie w ocenie funkcjonowania dziecka $z$ problemami stuchowymi w szkole
}

\section{S.I.F.T.E.R. and L.I.F.E.-R. tests and their application in the functioning of the child in school}

\author{
Agnieszka Ptaszkowska ${ }^{1}$, Aleksandra Jordan ${ }^{1}$, Zdzisław M. Kurkowski $^{1,2}$ \\ ${ }^{1}$ Uniwersytet Marii Curie-Skłodowskiej, Zakład Logopedii i Językoznawstwa Stosowanego, Lublin \\ ${ }^{2}$ Instytut Fizjologii i Patologii Słuchu, Światowe Centrum Słuchu, Warszawa/Kajetany
}

Adres autora: Agnieszka Ptaszkowska, Uniwersytet Marii Curie-Skłodowskiej, Zakład Logopedii i Językoznawstwa Stosowanego, ul. Sowińskiego 17, 20-040 Lublin, e-mail: a.ptaszkowska@wp.pl

\section{Streszczenie}

W artykule przedstawiono opis dwóch testów: S.I.F.T.E.R. - Screening Instrument For Targeting Educational Risk oraz L.I.F.E.-R. - Listening Inventory For Education - Revised oraz ich wykorzystanie w badaniach przeprowadzanych na przestrzeni lat przez różnych badaczy. Kwestionariusze te okazały się przydatnym narzędziem do oceny funkcjonowania dziecka z problemami słuchowymi w środowisku szkolnym. Niniejsza praca ma na celu przybliżenie wymienionych testów oraz dokonanie ich merytorycznej oceny.

Słowa kluczowe: S.I.F.T.E.R. • L.I.F.E.-R. • zaburzenia przetwarzania słuchowego • warunki akustyczne klasy • kształcenie integracyjne • ubytki słuchu

\begin{abstract}
The article describes two screening tests: S.I.F.T.E.R. - Screening Instrument For Targeting Educational Risk and L.I.F.E.-R. - Listening Inventory For Education - Revised and their use in research carried out over the years by different researchers. This paper aims to present analysis of the tests and emphasize their scientific contribution.
\end{abstract}

Key words: S.I.F.T.E.R. • L.I.F.E.-R. • APD • class acoustics • integrated education • hearing loss

\begin{abstract}
Wstęp
Problemy ze słuchem mogą mieć wpływ na funkcjonowanie dziecka w klasie. Zidentyfikowanie tych problemów oraz ich skutków często sprawia trudność pracownikom szkoły oraz audiologom szkolnym. Co roku u wielu dzieci w przesiewowych badaniach słuchu rozpoznawany jest pewien stopień ubytku słuchu. Często dzieci z rozpoznanymi trudnościami słuchowymi są włączane do klas ogólnodostępnych. Wielu nauczycieli w szkołach nie zdaje sobie sprawy, iż nawet niewielki ubytek słuchu występujący u ucznia może mieć negatywne skutki dla jego edukacji [1]. Uznaje się też, że dobra akustyka w klasie ma wpływ na prawidłowe słyszenie i rozumienie nauczyciela przez ucznia [2,3]. Opracowano wiele metod, które umożliwiają określenie takich aspektów akustyki w pomieszczeniach, jak poziom hałasu tła, pogłos lub stosunek sygnału do szumu (SNR). Do tej pory skonstruowano jednak
\end{abstract}

niewiele testów pozwalających ocenić jakość środowiska akustycznego w klasie z punktu widzenia zarówno nauczyciela, jak i ucznia.

\begin{abstract}
Niniejszy artykuł przedstawia dwa testy: S.I.F.T.E.R. - Screening Instrument For Targeting Educational Risk [1] oraz L.I.F.E.-R. - Listening Inventory For Education - Revised [4], które służą do oceny funkcjonowania dzieci z problemami słuchowymi w szkole. Żaden z nich nie był wcześniej przetłumaczony na język polski, ani zaadaptowany do realiów panujących w Polsce. Celem autorów niniejszego artykułu jest pokazanie wartości merytorycznej obu testów oraz wskazanie możliwości ich wykorzystania, w odniesieniu do przeprowadzonych badań opisanych w literaturze obcojęzycznej.
\end{abstract}




\section{Screening Instrument For Targeting Educational Risk (S.I.F.T.E.R.)}

S.I.F.T.E.R. został opracowany i opublikowany przez K. Anderson w 1989 roku [1], która od wielu lat specjalizuje się w audiologii dziecięcej i edukacyjnej.

Pierwotnie narzędzie to miało stanowić pomoc w wychwytywaniu uczniów z problemami słuchowymi, jednak okazało się przydatne także do oceny skuteczności zastosowanych pomocy akustycznych w klasie (np. aparatów słuchowych). Testy, przeprowadzone przed zastosowaniem i po zastosowaniu urządzeń wzmacniających dźwięki, pozwalają oceniać rezultaty wykorzystania tej formy pomocy w klasie oraz jej wpływ na wyniki nauczania [5].

S.I.F.T.E.R. jest kwestionariuszem przydatnym do oceny funkcjonowania dziecka w szkole. Jego celem jest identyfikacja i obserwacja uczniów z zaburzeniami słuchu, którzy mogą być narażeni na obniżenie szans edukacyjnych $\mathrm{w}$ porównaniu $\mathrm{z}$ normalnie słyszącymi rówieśnikami. Test ułatwia ocenę zachowań uczniów, które mogą przyczynić się do osiągania przez nich sukcesów szkolnych, przede wszystkim w klasie integracyjnej [6].

S.I.F.T.E.R. jest narzędziem do oceny dzieci korzystających z:

- aparatów słuchowych,

- implantów ślimakowych,

- systemów FM,

- pętli indukcyjnych.

Dzięki użyciu testu S.I.F.T.E.R. jako pre-testu i post-testu każda zmiana w wynikach uczniów może zostać udokumentowana [5].

S.I.F.T.E.R. nie powinien być stosowany jako jedyne i niepodważalne kryterium przy ocenie dziecka, które ma wskazania do dodatkowych świadczeń (materialnych czy zdrowotnych), otrzymania specjalistycznego wsparcia czy urządzeń wspomagających percepcję słuchową. Może być wykorzystywany jedynie jako wskazówka dla nauczycieli pośród innych opinii i badań [5].

S.I.F.T.E.R. posiada trzy wersje:

- Screening Instrument For Targeting Educational Risk Preschool Version,

- Screening Instrument For Targeting Educational Risk Primary Version,

- Screening Instrument For Targeting Educational Risk in Middle and High School Students with Hearing Loss Secondary S.I.F.T.E.R.

Każda z wersji obejmuje pięć obszarów (po trzy pytania w każdym), odnoszących się do:

- uczenia się,

- uwagi,

- komunikacji,

- udziału w życiu klasy,

- zachowania w szkole.

Punkty w każdej sekcji są sumowane i określają wynik uczenia (pozytywny, na granicy normy lub negatywny). S.I.F.T.E.R. klasyfikuje uczniów do dwóch grup: ocenionej pozytywnie lub objętej możliwością wystąpienia trudności szkolnych [7].

\section{Screening Instrument For Targeting Educational Risk - Preschool Version (dla dzieci w wieku przedszkolnym)}

Problemy ze słuchem u dziecka mogą wpłynąć na jego prawidłową zdolność słuchania, uwagę, posługiwanie się językiem, rozumienie i wykonywanie poleceń nauczyciela oraz uczenie się. Skala ta została zaprojektowana jako narzędzie do identyfikowania tych dzieci, które są zagrożone problemami w rozwoju lub edukacyjnymi oraz potrzebują dalszej obserwacji i badań ze względu na trudności słuchowe. Analiza konkretnego obszaru oraz wyniki testu są pomocne w określeniu profilu dziecka, jego mocnych stron i specjalnych potrzeb. Profil ten może być przydatny przy formułowaniu ocen dotyczących funkcjonowania dzieci oraz udoskonalaniu ich indywidualnych programów edukacyjnych. Analiza wyników Preschool S.I.F.T.E.R. wykazała, że dwa czynniki: komunikacja językowa i normatywne zachowania społeczne odróżniają dzieci będące w normie od tych, które są w grupie ryzyka [8].

Osoby wypełniające Preschool S.I.F.T.E.R. muszą znać przebieg prawidłowego rozwoju i zachowania dzieci, gdyż porównują one dzieci z zaburzeniami słuchu do ich rówieśników w normie rozwojowej. Analiza danych pochodzących z testów Preschool S.I.F.T.E.R. wykazała, że:

- wyniki dzieci z różnymi stopniami ubytku słuchu są znacznie niższe niż wyniki dzieci z prawidłowym słuchem we wszystkich pięciu obszarach testu,

- komunikacja językowa jest czynnikiem, który najbardziej odróżnia dzieci w normie rozwojowej od tych, które są narażone na ryzyko wystąpienia problemów rozwojowych lub edukacyjnych,

- normatywne zachowania społeczne również są czynnikiem różnicującym dzieci, jednak w nieco mniejszym stopniu niż komunikacja językowa,

- płeć jest czynnikiem istotnym statystycznie w odniesieniu do kategorii takich jak zachowanie oraz komunikacja, ponieważ dziewczynki mają w teście nieco wyższe wyniki niż chłopcy,

- nie ma dowodów na to, iż rasa wpływa na wyniki testów [9].

\section{Screening Instrument For Targeting Educational Risk - Primary Version (dla uczniów w wieku szkolnym)}

Test S.I.F.T.E.R. został zaprojektowany na podobnych zasadach jak Preschool S.I.F.T.E.R. W odniesieniu do każdego ucznia, który uzyskał w tym teście małą liczbę punktów $\mathrm{w}$ zakresie uczenia, powinna zostać przeprowadzona bardziej szczegółowa ocena procesu kształcenia. W przypadku uzyskania niewielkiej liczby punktów w obszarze komunikacji powinna to być ocena mowy i języka, a w przypadku zachowań w szkole - ocena sporządzona przez psychologa lub pracownika socjalnego. Niewielka liczba punktów w obszarze uwagi i/lub udziału w życiu klasy w połączeniu z podobnym wynikiem w innych obszarach może sugerować potrzebę dokonania oceny przez audiologa. Dzieci, które uzyskały niskie wyniki w tym teście, są narażone na ryzyko pogorszenia się ich umiejętności szkolnych i powinny być monitorowane [7]. 


\section{Screening Instrument For Targeting Educational Risk in Middle and High School Students with Hearing Loss - Secondary S.I.F.T.E.R. (dla uczniów szkoły średniej)}

Uczniowie szkół średnich kształceni są zazwyczaj w stosunkowo dużych klasach, w których warunki akustyczne mogą wpływać niekorzystnie na pełny dostęp do informacji słownych. Osoba, która dorastała z ubytkiem słuchu, ma prawdopodobnie problemy $z$ rozumieniem języka, całkowitym zrozumieniem słownych instrukcji czy przekazywanych treści szkolnych oraz prowadzeniem rozmów $\mathrm{z}$ rówieśnikami [10].

U nastolatków często nie jest możliwe szybkie wykrycie niewielkich ubytków słuchu. Regularne monitorowanie uczniów za pomocą opisywanego testu może pomóc w określeniu, czy uczeń z wadą słuchu w pełni odbiera polecenia słowne w warunkach panujących w typowej klasie. Ważne jest więc, aby przeprowadzać badania przede wszystkim w szkołach, w których jest głośno, a warunki akustyczne nie sprzyjają słuchaniu [7].

Omawiane kwestionariusze porównujące efekty nauczania dziecka są tak skonstruowane, aby w cokwartalnych lub corocznych badaniach wychwycić występujące zmiany. Zaleca się, aby każdy uczeń w klasie integracyjnej przeszedł badanie testem S.I.F.T.E.R. we wrześniu i w maju. Uczniowie korzystający w ostatnim czasie z urządzeń poprawiających słyszenie lub których wyniki uzyskane w kwestionariuszach były wątpliwe powinni zostać zbadani testem S.I.F.T.E.R. również $\mathrm{w}$ połowie roku szkolnego.

S.I.F.T.E.R. może być wykorzystywany przez kadrę nauczycielską do badania wszystkich uczniów z zaburzeniami słuchu, którzy nie są objęci dodatkowymi zajęciami edukacyjnymi. Często ubytek słuchu określony przez audiogram nie jest jednoznacznym wyznacznikiem trudności w nauce. Tylko określenie sprawności słuchowej pozwala na śledzenie postępów ucznia w nauce oraz ustalenie dla niego indywidualnego programu edukacyjnego [1].

\section{Listening Inventory For Education - Revised (L.I.F.E.-R.)}

Test Listening Inventory For Education (L.I.F.E.) został stworzony w 1998 roku przez K. Anderson i J. Smaldino [4]. Przeznaczony jest do badania uczniów od szóstego roku życia. Podstawowym celem L.I.F.E.-R. jest określenie stopnia indywidualnych trudności każdego dziecka $\mathrm{z}$ zaburzeniami słuchu w różnych warunkach akustycznych panujących w szkole. Ponadto test może być wykorzystywany do oceniania korzyści, jakie można osiągnąć poprzez zastosowanie w klasie urządzeń wspomagających słuchanie [11].

Od wielu lat L.I.F.E. był często stosowany jako skuteczne narzędzie do diagnozowania trudności szkolnych. W ciągu ostatnich lat sposoby kształcenia zmieniały się, stwarzając nowe wyzwania dla nauczycieli i uczniów. Klasy integracyjne stały się bardziej powszechne, przez co dzieci z deficytami słuchu znacznie częściej uczą się w szkołach ogólnodostępnych. Tworzenie takich warunków nauczania odgrywa ważną rolę w osiąganiu sukcesu edukacyjnego oraz społecznego dzieci w środowisku szkolnym. Ponadto na przestrzeni lat zarówno uczniowie, jak i nauczyciele coraz chętniej zaczęli korzystać $\mathrm{z}$ nowych rozwiązań technologicznych, wykorzystując programy komputerowe do tworzenia i analizowania różnych rozwiązań. $Z$ tych powodów w 2011 roku stworzono aktualizację L.I.F.E., która została rozszerzona do interaktywnej elektronicznej wersji Listening Inventories for Education - Revised (L.I.F.E.-R.) [12].

Test L.I.F.E.-R. ma następujące cele:

- dostarczenie uczniom narzędzi do oceny problematycznych i trudnych sytuacji akustycznych w klasie,

- dostarczenie nauczycielom narzędzi pomiarowych do dokumentowania efektów działań podjętych w celu poprawy warunków percepcji słuchowej każdego ucznia,

- dostarczenie narzędzia pomiarowego, które może być używane w formie pre-testu i post-testu, do dokumentowania skuteczności zastosowanych działań poprawiających warunki akustyczne w klasie,

- dostarczenie materiałów do poszerzania wiedzy kadry szkolnej na temat warunków akustycznych w klasach,

- dostarczenie nauczycielom i uczniom informacji o sposobie tworzenia właściwych warunków akustycznych w klasie $[13,14]$.

Test L.I.F.E.-R. składa się z dwóch kwestionariuszy:

- Student L.I.F.E-R. - Student Appraisal of Listening Difficulty (wersja dla ucznia),

- Teacher L.I.F.E.-R. - Teacher Appraisal of Listening Difficulty (wersja dla nauczyciela).

Powyższe testy - jeden przeznaczony dla ucznia, a drugi dla nauczyciela - mogą być stosowane jednocześnie, co umożliwia całościową ocenę zastosowanej interwencji w klasie. Każdy z testów może być też wykorzystywany samodzielnie, w zależności od tego, jakie informacje chce się uzyskać. Kwestionariusze zostały zaprojektowane tak, aby mogły być używane przez audiologów, logopedów, nauczycieli lub innych specjalistów pracujących z uczniami z zaburzeniami słuchu. Podczas badania nie jest wymagana znajomość materiałów oraz sposobów oceniania L.I.F.E.-R., lecz wskazane jest doświadczenie w pracy z dziećmi, które mają problemy ze słuchem [14].

\section{L.I.F.E.-R.: Student Appraisal of Listening Difficulty}

L.I.F.E.-R. Student Appraisal of Listening Difficulty składa się $\mathrm{z}$ trzech etapów.

Przed właściwą częścia testu L.I.F.E.-R uczeń rozwiązuje Questions for Students, czyli kwestionariusz składający się z sześciu pytań wielokrotnego wyboru, w którym opisuje swoje miejsce w klasie oraz warunki akustyczne występujące w różnych sytuacjach. Jest to pierwszy etap testu. Jego celem jest dokładne opisanie przez ucznia problemów ze słyszeniem oraz reakcji na różne sytuacje po to, aby dobrać odpowiednie rozwiązania (wzmocnienia akustyczne) do zastosowania w klasie.

Druga część testu składa się z opisu 10 sytuacji w klasie i 5 dodatkowych sytuacji akustycznych, które mogą zaistnieć w szkole. Uczeń przeglądając fotografie, czyta pytania w celu określenia poziomu trudności w danej sytuacji. Elektroniczna wersja L.I.F.E.-R. zawiera fotografie, które 
można wykorzystać u wszystkich dzieci, także takich, które przejawiają trudności w czytaniu i pisaniu. Odpowiedzi mogą być uzyskiwane od dzieci zarówno na drodze werbalnej, jak i niewerbalnej - poprzez wskazywanie obrazków, np. przez dzieci z obniżonymi umiejętnościami w mówieniu. Uczeń może oceniać sytuacje za pomocą pięciostopniowej skali punktowej, wskazując, czy sytuacja przedstawiona na fotografii jest „zawsze łatwa”, „w większości łatwa”, „czasami trudna”, „w większości trudna” lub „Zawsze trudna”. W przypadku, gdy dziecko ma trudności ze zrozumieniem niuansów skali pięciopunktowej, można zmienić format odpowiedzi, umożliwiając uczniowi wybór spośród trzech odpowiedzi: sytuacja „zawsze łatwa”, „czasami trudna” i „zawsze trudna”. Wyniki są sporządzane w formie elektronicznej na podstawie ocen podanych przez ucznia. Ponadto generowany jest raport, który zawiera indywidualne propozycje i wskazówki dla ucznia.

Trzecim etapem, wykonywanym po wprowadzeniu urządzeń wzmacniających słuchanie, jest zadanie uczniowi kolejnych sześciu pytań wielokrotnego wyboru, opisujących jego reakcje w trudnych dla niego sytuacjach. Celem tej części testu jest także krótkie ocenienie ucznia pod kątem jego umiejętności dbania o swoje prawa, które powinny być uwzględniane i respektowane w szkole [14].

\section{Teacher L.I.F.E.-R. - Teacher Appraisal of Listening Difficulty}

Test Teacher L.I.F.E.-R. jest drugą częścią testu L.I.F.E.-R., przeznaczoną do wypełniania przez nauczycieli. Zanim powstał Teacher L.I.F.E.-R., niektórzy specjaliści używali opisywanego wcześniej testu Screening Instrument For Targeting Educational Risk (S.I.F.T.E.R.) jako narzędzia badawczego. Test S.I.F.T.E.R. był wykorzystywany w badaniach typu pre-test i post-test. Opierając się na wieloletnim doświadczeniu badaczy w stosowaniu formularza S.I.F.T.E.R., stworzono Teacher L.I.F.E.-R. Pytania zawarte $\mathrm{w}$ tym teście dotyczą przede wszystkim uwagi uczniów oraz ich aktywności na zajęciach. Teacher L.I.F.E.-R. odzwierciedla i opisuje zmiany warunków akustycznych wpływające na zachowania dzieci. Kwestionariusz zawiera piętnaście pytań, a uśrednione wyniki zapisywane są według poniższego schematu:

- brak problemów ze słyszeniem lub bardzo rzadkie problemy,

- sporadyczne problemy ze słyszeniem,

- czasami występujące problemy ze słyszeniem,

- częste lub regularne problemy ze słyszeniem,

- prawie zawsze występujące problemy ze słyszeniem.

Nauczyciel odpowiada na dodatkowe osiem pytań, które opisują umiejętności uczniów w dziedzinie samooceny. W sytuacji, gdy odpowiedzi te zgadzają się z odpowiedziami uczniów, nauczyciel może określić potrzeby dzieci z problemami słuchowymi, a tym samym może opracować odpowiednie formy pomocy uczniom i śledzić ich postępy. Jeśli różnica pomiędzy pre-testem a post-testem wynosi 35 punktów, oznacza to, iż podjęta interwencja była skuteczna i bardzo korzystna. Mniejsza różnica wyników między testami wskazuje na mniejsze korzyści z wprowadzonych zmian [14].

Uczniowie z ubytkiem słuchu mogą mieć trudności z formułowaniem wypowiedzi słownych, m.in. z powodu utrudnionej komunikacji w klasie. Student L.I.F.E.-R. i Teacher L.I.F.E.-R. mogą pomóc w określeniu warunków akustycznych i wskazaniu nauczycielom najbardziej odpowiedniego miejsca w klasie, ułatwiającego uczniowi rozumienie słyszanych treści.

Wyniki opisywanych powyżej części testu L.I.F.E.-R. wykorzystywane są do tworzenia spersonalizowanych raportów, uwzględniających również stopień ubytku słuchu i ocenę zdolności słuchowych ucznia. Już w pierwszych tygodniach roku szkolnego można zakończyć z uczniami pierwszy etap testu L.I.F.E.-R., aby zdobyć wiedzę na temat ogólnej percepcji słuchowej dzieci w klasie. Informacje uzyskane od uczniów są przydatne, ponieważ dają nauczycielowi podstawy do zaproponowania zmian prowadzących do poprawienia środowiska akustycznego w klasie. Wyniki L.I.F.E.-R. mogą być omawiane z kadrą nauczycielską w celu lepszego zrozumienia potrzeb ucznia.

Identyfikacja i zrozumienie ograniczeń związanych $\mathrm{z}$ wadą słuchu sprawia, iż nauczyciel i uczeń są w stanie lepiej pokonać bariery akustyczne obecne w danej klasie i efektywniej korzystać z zastosowanych technologii wzmacniających dźwięk. Ponadto uczniowie mogą uczyć się umiejętności zwracania uwagi na własne potrzeby. L.I.F.E.-R. został zaprojektowany jako narzędzie przydatne nauczycielom i uczniom, dostarczając informacji o utrudnieniach akustycznych w klasie [14].

\section{Wykorzystanie testów S.I.F.T.E.R. i L.I.F.E.-R.}

Kwestionariusz S.I.F.T.E.R. został użyty w kilku recenzowanych publikacjach opisujących: jednostronny ubytek słuchu [15], lekki, odbiorczy ubytek słuchu [16], systemy FM [5], akustykę pomieszczeń [17], jak również skutki różnego rodzaju i stopnia ubytków słuchu $[7,18]$. S.I.F.T.E.R. był wykorzystywany także przez badaczy takich jak J. Gravel, I. Wallace [19] oraz C. Flexer, C. Richards, C. Buie [20] do badań przeprowadzanych wśród dzieci, u których wcześniej nie podejrzewano ubytku słuchu. Natomiast W. Wilson i wsp. [21] badali relację między testem S.I.F.T.E.R. a testami używanymi do wykrywania ryzyka zaburzeń centralnego przetwarzania słuchowego: Children's Auditory Performance Scale - CH.A.P.S. - W. J. Smoski, M. A. Brunt, J. C. Tannahill [22], Test of Auditory Perceptual Skills-Revised - T.A.P.S.-R. - M. Y. Gardner [23] oraz testami używanymi do audiologicznej oceny zaburzeń centralnego przetwarzania słuchowego: Test mowy filtrowanej (LPFS), Rozumienie zdań (CS), Test rozdzielnouszny cyfrowy (DDT), Test sekwencji tonów o różnej wysokości (FPT).

Badanie zostało przeprowadzone wśród 104 dzieci (71 chłopców i 33 dziewcząt) w wieku od 6 do 14 lat podczas ich pobytu w klinice Uniwersytetu Brisbane w Australii. Analiza wyników S.I.F.T.E.R., CH.A.P.S. oraz T.A.P.S.-R. wykazała brak przydatności tych testów do przewidywania indywidualnych wyników osiąganych w testach LPFS, CS, DDT lub FPT, jak również w stosunku do ogólnego ryzyka wystąpienia zaburzeń przetwarzania słuchowego. Wnioskiem wynikającym $z$ artykułu W. Wilsona i wsp. [21] jest to, iż testy S.I.F.T.E.R., CH.A.P.S. oraz T.A.P.S.-R. powinny być stosowane w celu poprawy jakości opieki nad dzieckiem w szkole. Jednak nie należy ich wykorzystywać do diagnozy zaburzeń centralnego przetwarzania słuchowego. 
Wniosek ten jest zgodny z zaleceniami R. Schowa i J. Seikela [24], którzy stwierdzili, że te kwestionariusze nie są odpowiednimi testami do wykrywania zaburzeń centralnego przetwarzania słuchowego. Autorzy sugerują, iż można ich używać tylko do uzupełniania całościowej oceny dziecka i sytuacji warunkujących jego zachowania.

Z kolei projekt przeprowadzony przez C. Taub i wsp. [25] miał na celu wykazanie efektów w uczeniu się w sytuacji zastosowania w klasie systemów wzmacniających dźwięk. Wykrywanie dzieci $\mathrm{z}$ trudnościami w nauce przeprowadzono za pomocą Preschool S.I.F.T.E.R., natomiast do badania ich świadomości fonologicznej użyto testu T.O.P.A. (wersja dla dzieci w wieku przedszkolnym). Badanie trwało cztery miesiące i wzięło w nim udział 38 dzieci w wieku przedszkolnym. Grupa badana złożona była z 19 uczniów, wśród których 9 było dwujęzycznych lub zdiagnozowanych jako dzieci ze znacznie ograniczoną znajomością języka angielskiego. Grupa kontrolna składała się z 19 dzieci, u których dominującym językiem był angielski. Wszystkie dzieci przeszły przesiewowe badanie audiologiczne przy użyciu testów określonych przez ASHA w czasie dwóch tygodni poprzedzających projekt [26]. Następnie zmierzono poziom natężenia dźwięku w pustej klasie. Uzyskano wynik $>50 \mathrm{dBA}$, a kiedy dzieci były obecne w klasie, podwyższono poziom natężenia do $74 \mathrm{dBA}$ (grupa badana) i $68 \mathrm{dBA}$ (grupa kontrolna). Do przeprowadzenia oceny uczniów wykorzystano kwestionariusz Preschool S.I.F.T.E.R. Wyniki wykazały, że liczba dzieci przypisanych do kategorii „wysokiego ryzyka” w Preschool S.I.F.T.E.R. znacznie zmalała w grupie badanej, czyli wśród dzieci, u których zastosowano wzmocnienie dźwięków. Znaczna poprawa wyników uczniów wystąpiła mimo faktu, iż w grupie badanej znajdowały się wszystkie dzieci, które zostały określone jako dwujęzyczne lub scharakteryzowane jako dzieci o ograniczonej znajomości języka angielskiego.

F. Kuk i wsp. [27] ocenili potrzebę zastosowania cyfrowych aparatów słuchowych z mikrofonem kierunkowym w grupie dzieci w wieku szkolnym. Dwadzieścioro dzieci w wieku 7-14 lat (9 uczniów z lekkim lub umiarkowanym niedosłuchem oraz 11 uczniów z niedosłuchem znacznym lub głębokim) nosiło obuusznie aparaty słuchowe (bez mikrofonu kierunkowego). Następnie przez trzydzieści dni korzystali oni z aparatów z mikrofonem kierunkowym. W badaniu uzyskanych efektów wykorzystano Speech Recognition Test, czyli test do rozpoznawania mowy. Z kolei subiektywną ocenę skuteczności zastosowanych aparatów słuchowych w warunkach klasowych zbadano za pomocą kwestionariusza L.I.F.E. Przeanalizowano także wypowiedzi rodziców dotyczące oceny korzyści z zastosowania aparatów słuchowych u ich dzieci. W przeprowadzanym badaniu uczniowie zostali podzieleni na dwie grupy w zależności od stopnia ubytku słuchu. Pierwsza grupa otrzymała aparaty słuchowe $\mathrm{z}$ umiarkowanym wzmocnieniem (Senso C9), a druga ze znacznym wzmocnieniem (Senso C19). Porównano średnie oceny uczniów między badaniem wykonanym w ich własnych aparatach słuchowych (pre-test) oraz przy użyciu aparatów z mikrofonem kierunkowym (post-test). Kwestionariusz L.I.F.E. wykazał, iż dzieci uzyskały lepsze wyniki, gdy korzystały $\mathrm{z}$ aparatów słuchowych z mikrofonem kierunkowym, niż gdy nosiły swoje własne aparaty. Odnotowano, iż opisywane aparaty umożliwiają dzieciom polepszenie rozumienia wypowiedzi. Aparaty słuchowe z mikrofonem kierunkowym zostały ocenione lepiej niż aparaty słuchowe należące do uczniów w wielu sytuacjach akustycznych wymienionych w kwestionariuszu L.I.F.E.

B. Darai [28] zbadała wpływ zastosowania systemu FM w klasie na umiejętności czytania i pisania wśród 166 uczniów klasy pierwszej (85 osób w grupie badanej i 81 osób w grupie kontrolnej). W badaniach wykorzystano test Informal Reading Inventory (IRI) do oceny umiejętności czytania i pisania oraz test Teacher L.I.F.E. w celu identyfikacji zmian uwagi dzieci i sposobów uczenia się $\mathrm{w}$ wyniku zastosowania w klasie wzmocnień akustycznych. W projekcie wzięło udział osiem klas pierwszych z Broward County Public School. Cztery klasy z grupy badanej stosowały system FM przez pięć miesięcy. Pozostałe cztery klasy stanowiły grupę kontrolną. Każdy system FM składał się z odbiornika telewizyjnego, nadajnika, mikrofonu oraz czterech głośników. Nauczyciele w klasie zostali poproszeni o niezmienianie dotychczasowego stylu i sposobu prowadzenia zajęć. Na zakończenie projektu badawczego wypełniono test L.I.F.E., który wykazał, iż zastosowanie systemu FM w klasach było korzystne dla dzieci. Okazało się, że uczniowie w klasach z systemem FM osiągali lepsze wyniki w przeprowadzonych testach w porównaniu $\mathrm{z}$ grupą kontrolną. Stosowanie systemu FM zostało pozytywnie ocenione przez wszystkich nauczycieli. Informowali oni, iż uczniowie $\mathrm{w}$ klasach $\mathrm{z}$ zastosowanym wzmocnieniem lepiej reagowali na polecenia słowne, wzrastała ich uwaga, dzięki czemu nauczyciele rzadziej musieli powtarzać wypowiedzi i mogli mówić z naturalnym nastawieniem głosu. W klasach, w których zastosowano system FM, u uczniów dwujęzycznych i uczniów ze specjalnymi potrzebami edukacyjnymi bardziej zauważalny był także wzrost umiejętności czytania. Analiza I.R.I. i L.I.F.E. ujawniła potrzebę wprowadzania zmian akustycznych w klasach w celu poprawy umiejętności pisania i czytania [28].

K. Anderson i J. Smaldino [29] w studium przypadku opisali chłopca $\mathrm{z}$ trudnościami w szkole, które mogły wynikać $\mathrm{z}$ jego problemów ze słuchem. $Z$ badań audiologicznych wynikało, iż średni próg słyszenia chłopca wynosi 35 dB. Uczeń wypełnił test Student L.I.F.E., a kwestionariusz Teacher L.I.F.E. został wysłany do szkoły. Wyniki tych testów zostały wykorzystane jako dodatkowe kryterium przy doborze aparatu słuchowego w celu umożliwienia chłopcu poprawy słyszenia w trudnych dla niego warunkach akustycznych.

J. W. Hall i wsp. [11] przeprowadzili badanie, w którym dzieci z zaburzeniem przetwarzania słuchowego otrzymały urządzenia FM - Phonak EduLink do użytku w domu i w klasie. Wyniki w nauce sprawdzono za pomocą dwóch testów - S.I.F.T.E.R. i L.I.F.E. Testy zostały przeprowadzone dwa razy, w odstępie co najmniej pięciu miesięcy od zastosowania systemu FM w klasie. Grupę kontrolną stanowiło 13 uczniów w normie słuchowej, a grupę badaną 10 dzieci z zaburzeniami przetwarzania słuchowego. Analiza wyników testu S.I.F.T.E.R. wykazała, że zastosowanie systemu FM spowodowało polepszenie wyników wśród dzieci z zaburzeniem przetwarzania słuchowego i poprawę prawie każdej mierzonej funkcji. Samoocena uczniów w teście L.I.F.E. ujawniła, że przed użyciem systemu EduLink dzieci z zaburzeniem przetwarzania słuchowego oceniały 
siebie jako bardziej narażone na trudności w nauce w porównaniu z dziećmi z grupy kontrolnej. Badania pre-test i post-test ujawniły, że w hałasie uczniowie z zaburzeniami przetwarzania słuchowego używający systemu FM EduLink mieli znaczącą przewagę w wynikach testów nad rówieśnikami z grupy kontrolnej. Dane z testów S.I.F.T.E.R. i L.I.F.E. potwierdziły zatem korzyści z używania indywidualnego systemu FM w klasie przez dzieci z zaburzeniem przetwarzania słuchowego, polegające na lepszej zdolności rozumienia wypowiedzi nauczyciela w klasie, możliwości lepszej komunikacji i niższym poziomie stresu.

\section{Wnioski}

Wnioski płynące z badań przeprowadzonych za pomocą testów S.I.F.T.E.R i L.I.F.E.-R wskazują na ich przydatność do uzyskiwania informacji o subiektywnych ocenach uczniów i nauczycieli dotyczących warunków akustycznych panujących w klasie. Dzięki przeprowadzeniu obydwu testów możliwe jest dostrzeżenie dodatkowych problemów uczniów z zaburzeniami słuchu i zaplanowanie indywidualnego programu wsparcia dla nich.

Po przeanalizowaniu opisywanych testów oraz publikacji dotyczących ich wykorzystania autorzy niniejszego artykułu uważają za zasadne zaadaptowanie tych kwestionariuszy i przystosowanie ich do warunków istniejących w polskim szkolnictwie. Pozwoliłoby to na dostarczenie nauczycielom konkretnego narzędzia do monitorowania osiągnięć uczniów z uwzględnieniem warunków akustycznych panujących w klasie. Narzędzia te byłyby ponadto przydatne do oceny korzyści, jakie odnoszą uczniowie dzięki różnym technologiom wspierającym słyszenie. Ponadto zidentyfikowanie problemów akustycznych ograniczających funkcjonowanie ucznia w szkole może być pierwszym krokiem do tworzenia odpowiednich, zindywidualizowanych warunków uczenia się w klasie, mogących przyczynić się do zwiększenia samodzielności uczniów oraz ich komfortu psychicznego. Autorzy uważają, iż możliwe jest stworzenie elektronicznych wersji omawianych testów, co ułatwiłoby ich rozpowszechnienie. Zastosowanie wersji komputerowej usprawni przeprowadzenie badań oraz przeanalizowanie wyników, dzięki czemu nauczyciele będą mogli szybciej sformułować wnioski dotyczące pomocy dzieciom, w szczególności tym uczącym się $\mathrm{w}$ klasach integracyjnych.

Artykut powstat $w$ związku $z$ realizacja projektu „Zintegrowany system narzędzi do diagnostyki i telerehabilitacji schorzeń narzadów zmysłów (słuchu, wzroku, mowy, równowagi, smaku, powonienia)" wspótfinansowanego przez Narodowe Centrum Badań i Rozwoju w ramach Programu STRATEGMED.

\section{Piśmiennictwo:}

1. Anderson K. Screening Instrument For Targeting Educational Risk (SIFTER) in Children with Identified Hearing Loss. Tampa. FL: Educational Audiology Association; 1989, www. sifteranderson.com

2. Crandell C, Smaldino J, Flexer C. Sound Field Amplification: applications to speech perception and classroom acoustics. Clifton Park: Delmar Learning, 2005; $2^{\text {nd }}$ Edition: 115-31.

3. Smaldino J, Flexer C. Handbook of acoustic acessibility. New York: Thieme Medical Publishers; 2012.

4. Anderson K, Smaldino J. The Listening Inventory for Education (LIFE). FL: Educational Audiology Association; 1998, www.sifteranderson.com

5. Tharpe AM, Ricketts T, Sladen DP. FM Systems for children with minimal to mild hearing loss. ACCESS: Achieving Clear Communication Employing Sound Solutions. Phonak Proceedings; 2003, http://www.phonak.com/professional/informationpool/proceedings.htm

6. Anderson K. Secondary SIFTER User's Manual. Tampa. FL: Educational Audiology Association; 2004, www.sifteranderson.com

7. Anderson K. Holistic Assessment Annual Conference - BATOD South Conference; 2006, http://www.batod.org.uk/content/batod/regions/south/conf-06/sifter.pdf

8. Anderson K, Matkin N. Preschool Screening Instrument for Targeting Educational Risk (SIFTER) in children age 3-Kindergarten. Tampa. FL: Educational Audiology Association; 1996, www.sifteranderson.com

9. Anderson K, Matkin N. Screening Inventory for Targeting Educational Risk - Preschool Version (Preschool S.I.F.T.E.R.); 2002, http://home.earthlink.net/ karenlanderson/presifter.html

10. Anderson K. Secondary SIFTER Screening Instrument For Targeting Educational Risk in Middle and High School Students with Hearing Loss. Karen L, Anderson S, red.; 2002, http:// home.earthlink.net/ karenlanderson/SecondarySifter.html
11. Hall J, Johnston K, John A, Crandell C. Multiple benefits of Phonac EduLink use by children with Auditory Processing Disorder (APD). Int J Audiol, 2009; 48(6): 371-83.

12. Robyn J. Listening Inventories for Education (LIFE). http:// robynblack.weebly.com/uploads/2/1/6/5/21656452/listening inventory_for_education_life.pdf

13. Anderson K, Smaldino J. Listening Inventory for Education L.I.F.E.; 2002, http://home.earthlink.net/ karenlanderson/life. html

14. Anderson K, Smaldino J, Spangler C. LIFE-R The Listening Inventories for Education - Revised; 2011, www.successforkidswithhearingloss.com/tests

15. Dancer J, Burl NT, Waters S. Effects of unilateral hearing loss on teacher responses to the SIFTER. Screening Instrument for Targeting Educational Risk. American Annals of the Deaf, 1995; 140(3): 29-94.

16. Bess FH, Dodd-Murphy J, Parker RA. Children with minimal sensorineural hearing loss: prevalence, educational performance, and functional status. Ear Hear, 1998; 9(5): 339-54.

17. Crandell CC, Kreisman BM, Smaldino JJ, Kreisman NV. Room acoustics intervention efficacy measures. Seminars in Hearing. Classroom Acoustics, 2004; 25(2): 201-6.

18. Most T. The effects of degree and type of hearing loss on children's performance in class. Deafness \& Education International, 2004; 6(3): 154-66.

19. Gravel JS, Wallace IF. Early otitis media, auditory abilities, and educational risk. American Journal of Speech-Language Pathology, 1995; 4(3): 89-94.

20. Flexer C, Richards C, Buie C. Soundfield Amplification for regular Kindergarten and first classrooms: A longitudinal study of fluctuating hearing loss and pupil performance. Paper presented at the American Academy od Audiology Convention. Phoenix; 1993. 
21. Wilson WJ, Jackson A, Pender A, Rose C, Wilson J, Heine C i wsp. The CHAPS, SIFTER, and TAPS-R as predictors of (C) AP skills and (C)APD. J Speech Lang Hear Res, 2011; 54: 278-91.

22. Smoski WJ, Brunt MA, Tannahill JC. Children's Auditory Performance Scale. Tampa. FL: The Educational Audiology Association; 1998.

23. Gardner MY. Test of Auditory Perceptual Skills - Revised. Austin. TX: Pro-Ed.; 1997.

24. Schow RL, Seikel JA. Screening for (central) auditory processing disorder. W: Musiek FE, Chermak GD, red. Handbook of (central) auditory processing disorder: Auditory neuroscience and diagnosis. 2007; 1: 137-59.
25. Taub CF, Kanis R, Kramer L. Reducing acoustic barriers in classrooms: A report comparing two kindergarten classrooms in an inner-city school. Journal of Educational Audiology, 2003; 11: 69-74.

26. American Speech-Language-Hearing Association. Guidelines for audiologic screening. Rockville; 1996.

27. Kuk F, Kollofski C, Brown S, Melum A, Rosenthal A. Use of a digital heraing aid with directional microphones in school-aged children. J Am Acad Audiol, 1999; 10: 535-48.

28. Darai B. Using sound field FM System to improve literacy scores. Advance for Speech-Language Pathologists \& Audiologists, 2000; 10(27): 5-13.

29. Anderson K, Smaldino J. Listening inventories for education: A classroom measurement tool. The Hearing Journal, 1999; 52(10): 74-75. 